\title{
Study on the Academic and Business Partnership in Economists Training
}

\author{
Olga Luskatova \\ Department of Finance \\ Vladimir Branch of the Russian Presidential Academy of \\ National Economy and Public Administration \\ Vladimir, Russia \\ E-mail: oluskatova@mail.ru
}

\author{
Andrey Mishin \\ Department of Accounting and Finance \\ Vladimir State University Named After Alexander and \\ Nikolay Stoletovs \\ Vladimir, Russia \\ E-mail: amishin@vlsu.ru
}

\begin{abstract}
The following article describes the issues of academic society and business partnership. Training of employees of credit institutions requires the development of modern methods of cooperation between universities and employers. This is most clearly reflected in the implementation of the competency-based approach in the multi-stage training of senior specialists. When using the integrative model of interaction between the University and the business community the universities of Vladimir region pay great attention to the work of the basic departments that have been created in close cooperation with permanent partnersemployers. The consideration of the requirements of business representatives is reflected in the results of professional and public accreditation of bachelors and masters.
\end{abstract}

Keywords-integrative model; competency-based approach; business community; banking industry

\section{INTRODUCTION}

The processes of international mobility of specialists with higher education require comparability of national educational systems and criteria for the quality of education. These processes refreshed attention to the problem of assessing the quality of specialists training by employers, as the professional requirements of financiers, even in the international context, are uniform. It is obvious that the assessment of the quality of education addresses two aspects: on the one hand, the assessment is a management element that also provides feedback in the system, and on the other hand, the assessment process identifies different requirements (criteria) for education by related parties, which is important from a practical point of view.

The variability of the economic situation, new financial instruments impose special requirements on specialists with higher economic education. The increase of work associated with the introduction and maintenance of new financial instruments requires practice-oriented knowledge, tools and conditions for financial tasks execution.

Public organizations and financial departments of companies are increasingly interested in saturating all parts of the workforce with creativity, analytical skills, and a tendency to search for new in the field of their activities, initiative and social responsibility for the results of their work. This is essentially a strategic personnel policy, promoting the need for continuous updating of knowledge and the development of new professions and specialties as the basic principles of employment.

\section{Methodology}

For the education system, these are the most pressing issues, because today one of the most relevant and "mutually beneficial" areas of interaction between business and education is the participation of employers in the development of the content of education (according to sociological research, more than $80 \%$ of employers are ready for that). For employers the participation in the development of educational content provides training in accordance with the objectives of the development of the organization, and the improving the efficiency and quality of services, and for higher education, taking into account the needs of a particular Bank allows to prepare competitive professionals demanded in the regional labor markets.

While composing the basic educational programs partner companies together with higher education institutions of the region have the opportunity to determine the knowledge and skills that will be in demand in professional activities.

The intercommunication of training at the University with the banking sector allows for widespread use of multistage training of senior specialists (bachelors and masters), and each stage of training will be able to have the character of professional completion. Multistaging makes the educational model more adapted to the interests and opportunities of the individual and the needs of employers, based on the relationship of teaching staff of the University and credit institutions, combined with the strengthening of General scientific, general professional and special training.

Thus, the integration of the University with employers is an objective trend in the development of professional education at the present stage.

\section{MODEL OF EDUCATION AND BUSINESS COOPERATION}

The process of interaction between educational institutions and employers is still insufficiently studied and is 
a high-demanded reserve to improve the efficiency of development, both higher education and the business community. This problem is especially actualized and complicated in the conditions of the knowledge economy, which is characterized by changes in the content, nature of labor, new requirements for the quality of the labor force on the part of business. [1]
Universities face a dual task of training qualified personnel who can quickly adapt to new labor conditions, and the growth of the share of graduates employed in the specialty after graduation.

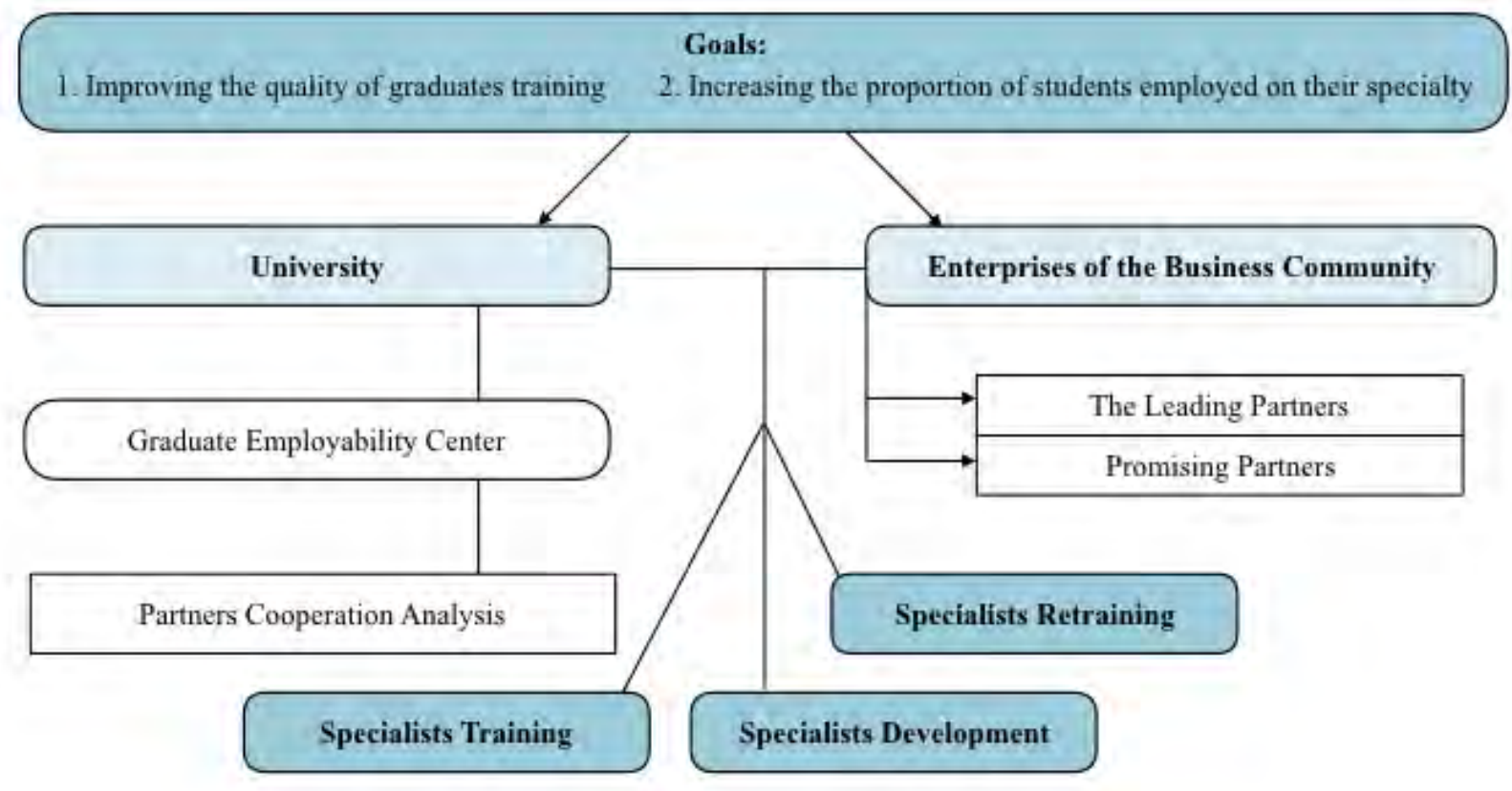

Fig. 1. The integrative model of effective partnership of universities and the business community.

The main way to solve these problems is to develop "University - Business Community Partnerships". In this regard, the development of an integrative model of effective interaction between universities and business is relevant (see "Fig. 1").

The work of this model depends on creation of a system of effective communication between University and the business community. The employer must have information about the teaching staff of the University, material and technical equipment, the most distinguished graduates, the features of education, conferences. It is necessary to create a database of graduates, containing key information personal data, education, and the topic of graduation papers, foreign language skills, computer skills, competitions, conferences and grants achievements.

Potential employers should take part in the assessment of the quality of specialists during the work of the state examination commissions.

Interaction between universities and enterprises should be carried out not only in the process of training, but also in retraining and advanced training of managers, specialists and employees.

The major thing in the development of partnerships is the conclusion of long-term contracts between universities and enterprises, in particular with the leading partners. The list of companies engaged in close cooperation with the University is given on the websites of universities to guide students on possible employment. This information is useful for students, as it allows determining the place of practical training. For Vladimir state University, as a reference University of the region, an important direction of development of communication with employers was the creation of basic departments with the leading partner enterprises.

\section{MAIL TOOLS AND IMPLEMENTATION}

As the main tool, that provides industrial, financial organizations and public authorities with qualified personnel, and the student with the necessary professional, social, communicative and other competencies is the competencebased approach implemented in the preparation of students according to Federal state standards of higher education, focused on the formation of key competencies of the graduate.

Competency-based training is most effectively implemented in the form of modular programmes, with the basic principle of training focused on the results required by employers. The module-competence approach fits into the concept of continuous education, since its purpose is to train highly qualified specialists capable of working in a constantly changing economic situation, on the one hand, and the continuation of professional growth and education on the other [3]. 
This approach really provides an increase in the efficiency and quality of training through the formation of the content and organization of training.

Module-competence approach allows integration of theoretical and practical training, rethinking the place and role of theoretical knowledge in the development of competencies. The advantage of competency-based modular programs is that their flexibility allows for updating or replacing individual specific modules when the requirements for graduates change, thereby ensuring the quality of training at a competitive level, and enables individualization of training by combining modules. The use of modular competence-based approach to training allows the institution to become the owner of the training intellectual resource.

It should be emphasized that the modular competence approach requires careful planning and organization of production practices, which requires close working contacts with employers. Students should be given ample opportunities to study in the workplace or in a situation that mimics the work environment as much as possible. This form of obtaining knowledge and skills allows the student to adapt to the reality of work in all its diversity and apply in practice not only professional, but also general cultural competence in different work situations [4].

It should be emphasized the maximum use of the competence approach in the transition of the University environment to the Federal State Education Standards 3++ (FSES 3++). The implementation of this methodological guideline required the development and adoption of a significant number of professional standards, including the economic specialties. The greatest difficulty in the implementation of new regulations is the distribution of professional competencies by levels of education. Detailing the activities and operations performed by individual workers requires higher education workers to deepen their theoretical knowledge and practical skills in accordance with each applicable professional standard. Competencies given in the standards require clarification in what level of training they will be achieved: college, bachelor, master.

The practical implementation of the approaches inherent in the model of collaboration between the University and the business community, for Vladimir State University was the creation of the joint Department of Banking in January 2014, on the basis of long-term Provisions on cooperation between the Vladimir branch № 8611 of OJSC "Sberbank of Russia" and Vladimir State University.

The Department provides training of students on the program "Modern Banking Technologies", developed jointly by specialists of Sberbank and the dedicated Department of Accounting and Finance. The program includes three modules:

- Introductory course (on the basis of Vladimir State University) - allows you to conduct occupational guidance for prospective students to assess their psychological attitudes and identify preferences for work in the structure of the Bank.
- The main course (on the basis of Sberbank) - allows training students in specific areas of work: lending to legal entities and individuals, the system of internal control and financial security, assessment of the creditworthiness of borrowers, the organization of work with troubled assets.

- Certification training (on the basis of Sberbank) obtaining a certificate to work in the relevant Department.

\section{PROGRAM DELIVERY PRINCIPLES}

- Programs are delivered using a blended learning approach, which involves a combination of in-class training, distance training, and self-study.

- Senior managers and other key executives of Sberbank are involved in program delivery as part of the Leaders Teaching Leaders initiative.

- The results of Sberbank's applied research forms the delivery and content of programs.

- In-class training is built around active learning methods, including interactive lectures and group work, and problem solving using case studies based on the experience of Sberbank Group and leading global companies.

- Business games and customized business simulations enrich the educational experience.

- Remote training technologies, such as virtual training environments (webinars, forums, and social networks), remote support for blended programs, ecourses for self-study, an e-library for recommended reading and online testing, maximize program flexibility.

- Programs are biased towards action learning through individual and group projects, "live" case studies, individual and group coaching.

- Programs culminate in a compulsory final assessment (exam, knowledge test, project presentation; students who successfully meet all program requirements are issued an official qualification document.

Upon completion of training, students receive a state diploma of professional retraining. Training period runs from February to September. This project allowed the teachers of the Department to learn more about the requirements of the main employer for economists-financiers, and the Vladimir branch of PJSC "Sberbank" to get the most trained graduates. As part of this training, the employer has the opportunity to retrain its employees. According to the results of the fiveyear functioning of the basic Department of Banking, the share of graduates employed in Sberbank is $84 \%$.

The Vladimir branch of the Russian Presidential Academy of National Economy and Public Administration in cooperation with the Vladimir branch of PJSC "Sberbank" is focused on internships during the semester. Flexible schedule allows you to combine full-time training of 
students-economists and full-time load in the credit institution. The form of internship contributes to the detailed study of a particular type of activity in the Bank, allows the employer to evaluate the future graduate and attract the most creative and initiative students.

Conditions of the competitive environment among employers have led to the significantly improved interaction of universities with VTB and Russian Agricultural Bank working in the territory of the region. Representatives of credit institutions for the purpose of selection of promising graduates conduct courses of lectures at universities, organize study tours in the offices of the banks, pay scholarships on a competitive basis to distinguished students involved in industrial practice.

The expert team of the Agency for professional public accreditation and independent assessment of qualifications (Profakkredagentstvo, Moscow), the basic expert-methodical organization of All-Russian Non-Governmental Organisation of Small and Medium Business ("OPORA Russia"), included representatives of the Federation of restaurateurs and hoteliers of Russia, specialized organizations and enterprises, members of "OPORA Russia". It was their opinion that was decisive in assessing the quality of training of students in the areas of "Management" (program "Management in tourism and hotel business") and "Economy".

"Within the framework of the examination, meetings were held with the heads of enterprises, where students have their practice, organizations where the graduates of the University are employed, more than 20 interviews with developers of educational programs, teachers, and specialists of various departments and services of the Institute. Independent experts organized a survey of graduates of previous years, were present during the final exams and defense of the graduate projects for professional qualification; they conducted direct assessment of professional competencies of masters on the ground of their own control and measuring materials. The work performed made it possible to create an objective idea of the practical orientation of the educational programs of the University."[2]

Positive feedback from independent experts on the level of training of masters of management of Vladimir State University was unanimously supported by the members of the accreditation Council "OPORA Russia". As a result, all the declared educational programs of the University received professional and public accreditation.

\section{CONCLUSION}

Thus, training of employees of credit institutions requires the development of modern methods of cooperation between universities and employers. This is most clearly reflected in the implementation of the competency-based approach in the multi-stage training of senior specialists. When using the integrative model of interaction between the University and the business community the universities of Vladimir region pay great attention to the work of the basic departments that have been created in close cooperation with permanent partners-employers. The consideration of the requirements of business representatives is reflected in the results of professional and public accreditation of bachelors and masters. The interaction of the University environment of the Vladimir region with the business community is in the process of continuous improvement. Close mutually beneficial partnership between the University and the business community at all stages of the educational process is the most productive way to obtain specialists with competencies in demand in the labor market at the present time.

\section{REFERENCES}

[1] D.A. Endovitskiy "The Strategic Partnership of the University and the Business Community: the Experience of Cooperation of Vladimir State University and NLMK", Vestnik VLSU, \#2, 2008, pp. 42-45.

[2] O.V. Luskatova "Professional Accreditation as a Form of Independent External Evaluation of the Quality of Educational Programs by Employers", Production practices, state certification, employment in higher education: organization, problems and solutions: Materials for All-Russian Research/Practice Conference held in February 4-5, 2014 in Vladimir, Vladimir publishing house of Vladimir State University, 2014, pp. 195-197.

[3] V.P. Medvedev, L.N. Denisova "Module-Competence Approach to New State Educational Standards", Fundamental Research, \#2, 2009, pp. 96-99 URL: www.rae.ru/fs/?section=content\&op=show_article\&article_id $=77815$ 02 (reference date - January 28, 2016).

[4] A.A. Mishin "The New Geography of Business Education Streams" in the book "Modern Problems and Tendencies of Development of Economy, Management and Informatics in the XXI Century", the book of scientific articles on the materials of scientific-practical conference with international participation, the department of "Financial University Under the Government of the Russian Federation", Saint-Petersburg branch, edited by L.K. Shamina, N.N. Shash, A.I. Sosnilo, E.O. Solovyova, O.P. Puzanova, M.Ya. Kreer, M. Yu. Chirkova, M. Yu. Volokobinskiy, E. Yu. Maiorova, 2016, pp. $158-160$ 